\title{
ANALISIS EFISIENSI FAKTOR PRODUKSI KARET DI KABUPATEN KAMPAR PROVINSI RIAU
}

\author{
Efficiency Analysis of Rubber Production Factor In Regency of Kampar \\ Riau Province
}

\author{
Heriyanto Heriyanto dan Darus Darus \\ Fakultas Pertanian Universitas Islam Riau. Jl. Kaharuddin Nasution 113, Pekanbaru 28284 Riau \\ Telp. : 0761-72126 ext. 123, Fax : 0761-674681 \\ [Diterima: Juli 2017; Disetujui: Agustus 2017]
}

\begin{abstract}
Kampar regency is one of the districts in Riau province which contributes significantly to the economy in Riau Province, especially in the agricultural sector in the plantation sector. Rubber is a leading commodity in the plantation subsector that continues to be the government's attention to develop. Rubber plantations have important roles and positions, both economically, socially, absorbing labor and ecological roles. Plantation is also a source of prosperity, progress, independence, and pride of Kampar district government. Plantation management at present still relies on and relies on the abundance of human resources are relatively cheap. Efficiency, productivity, quality, sustainability are still low. Rubber farmers are generally less aware of how to use efficient production factors to obtain high rubber yields. The accuracy of the use of production inputs is important for farmers to achieve production efficiency levels both technically, allocatively and economically. This study aims to analyze the efficiency of rubber production in Kampar regency by building multiple linear regression model and production efficiency analysis. The results showed that the dominant factors affecting rubber production in Kampar Regency were number of plants, plant age, number of labor and investment. The factors of production are the number of plants, and the amount of labor is not technically efficient, allocative, and economical. The use of fertilizers tends to be technically and economically efficient, but alocatively inefficient. In order to obtain optimal production, this study recommends the need for rejuvenation of old or damaged rubber plants using superior seeds and maintained in accordance with the standards of rubber cultivation techniques. The efficient use of labor can be achieved by applying a rubber tapping system appropriately tailored to the conditions of the plant and the price of rubber. In addition, the use of balanced fertilizers (elements $\mathrm{N}, \mathrm{P}$, and $\mathrm{K}$ ) in accordance with the recommended should be applied. Meanwhile, considering the fluctuating rubber prices and tend to vary between farmers, government intervention is required by applying a fair rubber auction market. Besides, there is an effort from farmers to maintain the quality of processed rubber.
\end{abstract}

Keywords: Dominant Factor, Production Efficiency, Rubber

\begin{abstract}
ABSTRAK
Kabupaten Kampar merupakan salah salah satu Kabupaten di Provinsi Riau yang ikut memberikan kotribusi yang cukup signifikan terhadap perekonomian di Provinsi Riau terutama pada sektor pertanian di sektor perkebunan. Karet merupakan komoditi unggulan pada subsektor perkebunan yang terus menjadi perhatian pemerintah untuk dikembangkan. Perkebunan karet mempunyai peran dan kedudukan yang penting, baik secara ekonomi, sosial, penyerap tenaga kerja maupun peran ekologi. Perkebunan juga merupakan sumber kesejahteraan, kemajuan, kemandirian, dan kebanggaan pemerintah kabupaten Kampar. Pengelolaan perkebunan pada saat ini masih mengandalkan dan bertumpu pada melimpahnya sumberdaya manusia yang relatif murah. Efisiensi, produktivitas, kualitas, keberlanjutannya yang masih rendah. Petani karet pada umumnya kurang mengetahui bagaimana penggunaan faktor - faktor produksi yang efisien untuk mendapatkan hasil produksi karet yang tinggi. Ketepatan penggunaan input produksi penting dilakukan petani dapat mencapai tingkat efisiensi produksi baik secara teknis, alokatif dan ekonomis. Penelitian ini bertujuan untuk
\end{abstract}


menganalisis efisiensi produksi karet di Kabupaten Kampar dengan membangun model regresi linier berganda dan analisis efisiensi produksi. Hasil penelitian memperlihatan bahwa faktor-faktor dominan yang mempengaruhi produksi karet di Kabupaten Kampar adalah jumlah tanaman, umur tanaman, jumlah tenaga kerja dan investasi. Faktor produksi jumlah tanaman, dan jumlah tenaga kerja tidak efisien secara teknis, alokatif, dan ekonomis. Penggunaan pupuk cenderung efisien secara teknis dan ekonomis, namun secara alokatif tidak efisien. Dalam rangka memperoleh produksi yang optimal, penelitian ini merekomendasikan perlunya peremajaan tanaman karet tua atau rusak dengan menggunakan bibit unggul dan dipelihara sesuai dengan standar teknik budidaya karet. Penggunaan tenaga kerja yang efisien dapat dicapai menerapkan sistem sadap karet yang tepat disesuaikan dengan kondisi tanaman dan harga karet. Disamping itu penggunaan pupuk berimbang (unsur N, P, dan K) sesuai dengan yang diajurkan perlu diterapkan. Sementara itu, mencermati kondisi harga karet yang berfluktuasi dan cenderung beragam antara petani maka diperlukan intervensi pemerintah dengan menerapkan pasar lelang karet yang fair. Disamping itu perlu adanya upaya dari petani untuk mempertahankan kualitas akan olahan karet.

Kata Kunci: Faktor dominan, Efisiensi Produksi, Karet.

\section{PENDAHULUAN}

Sektor pertanian di Indonesia dibagi menjadi lima subsektor yaitu subsektor pertanian pangan, subsektor perkebunan, subsektor kehutanan, subsektor peternakan dan subsektor perikanan. Sektor pertanian terus dituntut berperan dalam perekonomian nasional melalui pembentukan Produk Domestik Bruto (PDB), perolehan devisa, penyediaan pangan dan bahan baku industri, pengentasan kemiskinan, penyediaan lapangan kerja dan peningkatan pendapatan masyarakat.

Nilai Produk Domestik Bruto (PDB) dari hasil pertanian, peternakan, kehutanan dan perikanan atas dasar harga konstan 2000 adalah sebesar 304.777,1 miliar rupiah pada tahun 2010 dan 339.890,2 miliar rupiah pada tahun 2013 atau mengalami peningkatan sebesar 10,33 persen. Sedangkan peran sektor pertanian terhadap PDB Indonesia tahun 2013 turun dari 13,17 persen menjadi 12,89 persen. Peran sektor pertanian terhadap PDB berada pada peringkat ke dua setelah sektor industri pengelolaan yaitu sebesar 26,83 persen. (Badan Pusat Statistik Indonesia, 2014).

Kontribusi sektor pertanian terhadap total nilai PDRB Provinsi Riau ADHK-DM tahun dasar 2010 memiliki trend berfluktuatif meningkat. Pada tahun 2010, kontribusi sektor pertanian terhadap total nilai PDRB Provinsi

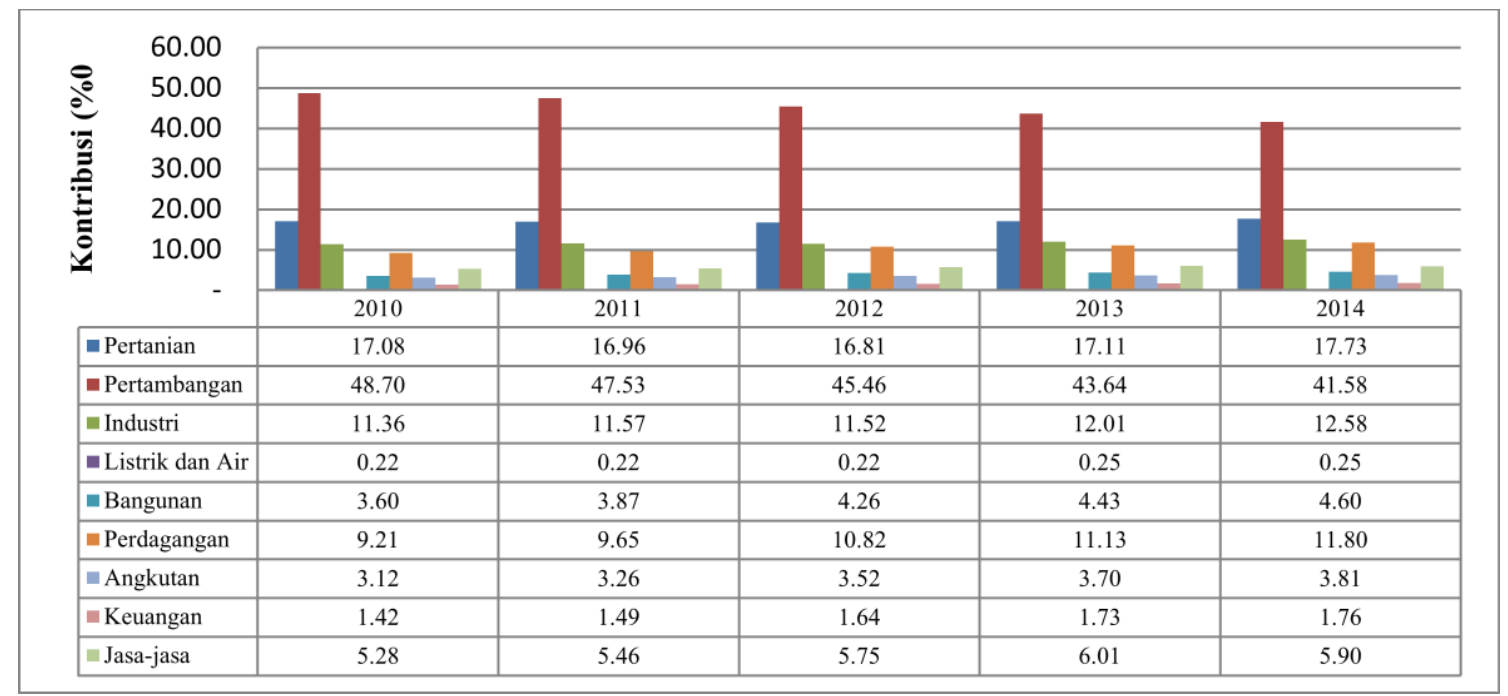

Sumber: BPS (Riau dalam Angka 2014 - 2015)

Gambar 1. Kontribusi PDRB Provinsi Riau Atas Dasar Harga Konstan 2000 Menurut Lapangan Usaha Termasuk Minyak Bumi dan Gas Tahun 2010-2014 
rendahnya produktivitas karet rakyat berdasarkan data dari Dinas Perkebunan Kabupaten Kampar hanya sebesar 0,78 ton/ ha/tahun, hal itu sebabkan oleh faktor-faktor antara lain : (1) mayoritas petani belum menggunakan bahan tanam klon karet unggul (okulasi) dan belum menerapkan standar budidaya serta pemeliharaan kebun karet dan juga teknologi pasca panen yang direkomendasikan, (2) terdapat areal kebun karet tua yang cukup luas yang perlu segera diremajakan. Faktor-faktor tersebut saling mempengaruhi satu sama lainnya. Faktor ini menjadi penentu sekaligus menjadi penghambat produksi terutama didaerah pedesaan sehingga masyarakat pedesaan khususnya petani karet yang mengalami masalah dalam usahanya untuk menigkatkan produksinya.

Berdasarkan telaah di atas secara umum penelitian ini dilakukan dengan tujuan untuk menganalisis efisiensi produksi karet di Kabupaten Kampar Secara spesifik bertujuan untuk menganalisis faktor-faktor dominan yang mempengaruhi produksi karet, menganalisis efisiensi teknis, efisiensi alokatif dan efisiensi ekonomi karet, dan Merumuskan implikasi kebijakan optimalisasi produksi karet di Kabupaten Kampar.

\section{METODOLOGI PENELITIAN}

Penelitian ini dilakukan di Kabupaten Kampar, menggunakan metode pengambilan sampel multy stage purposive sampling dengan kriteria memiliki luas lahan 1-3 ha dengan umur tanaman karet 13-25 tahun. Sampel diambil pada 3 kecamatan, yaitu Kecamatan Kampar Kiri Hulu, Kecamatan Kampar Kiri Hilir dan Kecamatan XIII Koto Kampar, karena ketiga kecamatan merupakan sentra produksi karet di Kabupaten Kampar. Masing-masing Kecamatan mengambil sebanyak 20 petani karet dan total sampel sebanyak 60 petani karet

Metode analisis data dalam penelitian ini menggunakan fungsi produksi Cobb-Douglas. Fungsi Cobb-Douglas adalah suatu fungsi atau persamaan yang melibatkan dua atau lebih peubah. Secara matematik, fungsi CobbDouglas dapat dituliskan sebagai berikut (Koutsoyiannis, 1997; Soekartawi, 2003):

$\mathrm{Y}=\mathrm{b} 0 \mathrm{X} 1 \mathrm{~b} 1 \mathrm{X} 2 \mathrm{~b} 2 \mathrm{X} 3 \mathrm{~b} 3 \quad \mathrm{X} 4 \mathrm{~b} 4 \quad \mathrm{X} 5 \mathrm{~b} 5 \mathrm{eu}$ Dimana:
$\mathrm{Y}=$ Jumlah produksi karet (Kg/hektar/tahun)

$\mathrm{X} 1$ = Jumlah Tanaman (Pohon/hektar/tahun)

$\mathrm{X} 2$ = Umur tanaman (hektar/tahun)

$\mathrm{X} 3$ = Penggunaan pupuk (Kg/hektar/tahun)

$\mathrm{X} 4$ = Jumlah tenaga kerja (HKP/Hektar/tahun)

$\mathrm{X} 5$ = Investasi (Rp/hektar/tahun)

b0 = Intersep

b1 ...b5 = Farameter faktor produksi yang akan diduga

e $\quad$ Logaritma natural, $\mathrm{e}=2,718$

$\mathrm{u}=$ Kesalahan pengganggu

Persamaan tersebut akan diubah kedalam bentuk linier berganda untuk memudahkan perhitungan dengan menggunakan transformasi logaritma natural, parameternya ditentukan dengan menggunakan metode Jumlah Kuadrat Terkecil (Ordinary Least Square / OLS ) sehingga persamaan menjadi sebagai berikut:

$\mathrm{Ln} Y=\mathrm{Ln} b 0+\mathrm{b} 1 \mathrm{Ln} \mathrm{X} 1+\mathrm{b} 2 \mathrm{Ln} \mathrm{X} 2+\mathrm{b} 3 \mathrm{Ln}$ $\mathrm{X} 3+\mathrm{b} 4 \operatorname{Ln} \mathrm{X} 4+\mathrm{b} 5 \operatorname{Ln} \mathrm{X} 5+\mathrm{u}$

Tanda parameter dugaan yang di harapkan (Hipotesis) b1, b2, b3, b5> 0 dan b4 < 0 .

Agar memberikan hasil yang valid secara ekonometrik perlu dilakukan pengujian beberapa asumsi ekonometrika yang meliputi pendekteksian normalitas, multikolinieritas, heteroskedastisitas dan autokorelasi dari persamaan dalam model regresi (Gujarati, 2003).

Pendeteksian normalitas dilakukan untuk mengetahui apakah variabel berdistribusi normal atu tidak dengan menggunakan ShapiroWilk dengan formula sebagai berikut (Thomas, 1997; Verbeek et all., 2000):

$$
\begin{aligned}
& \mathrm{W}=\frac{\left[\begin{array}{lll}
\sum & n(\tilde{\mathrm{e}} & )
\end{array}\right]}{\sum_{i}^{h}} \\
& \mathrm{~V}=\mathrm{T}-\mathrm{k} \mathrm{nj}
\end{aligned}
$$

$\mathrm{H}=\mathrm{n} / 2$ untuk bilangan genap atau (n-1) untuk bilangan ganjil, dimana $: \mathrm{v}=$ derajat bebas; $\mathrm{T}=$ jumlah observasi; $\mathrm{K}=$ jumlah variabel; ain = parameter dari statistik Shapiro-Wilk.

Uji multikolinieritas digunakan untuk mengetahui apakah terdapat korelasi antara peubah independen dalam model regresi. Untuk mendektesi multikolinieritas dalam suatu model dilakukan dengan melihat Variance Inflation 
Factor (VIF) dengan persamaan, sebagai berikut (Hanke, et.all., 2001; Thomas, 1997):

Variance Inflation Factor $=1 /$ tolerance

Masalah multicollinearity menjadi sangat serius jika nilai variance inflation factor lebih besar dari 10 sedangkan masalah multicollinearity diangap tidak serius jika nilai variance inflation factor lebih kecil sama dengan 10.

Pendeteksian heteroskedastisitas digunakan untuk mengetahui apakah varian dari variabel pengganggu tidak konstan untuk semua observasi. Pendeteksian masalah heteroskedastisitas menggunakan BreuschPagan test (Thomas, 1997; Verbeek et all., 2000) di bawah ini:

$$
\sigma_{i}^{2}=\sigma^{2} h\left(z_{i}^{1} \alpha\right)
$$

dimana:

$\mathrm{h}=$ unsur yang tidak diketahui, yaitu fungsi yang diturunkan secara kontinu (tidak tergantung pada i) sehingga $h()>$.0 dan $h(0)=1$.

$\mathrm{s} \quad=$ varian

$\mathrm{z}=$ peubah yang mempengaruhi distrubance terms variance.

Nilai Statistik Bruesch-Pagan yang tidak signifikan menunjukkan tidak terjadi masalah heteroskedastisitas

Autokolerasi digunakan untuk mengetahui apakah dalam suatu model regresi linier terdapat korelasi antara anggota observai satu dnegan observasi lain yang berlainan waktu. Untuk menguji autokorelasi dengan menggunakan Durbin Watson, dengan formula sebagai berikut (Pindyck and Rubinfeld, 1998; Thomas, 1997):

$\mathrm{d}=\frac{\left[\sum_{t=1}^{t=n}\left(\hat{\mathrm{e}}_{t}-\hat{\mathrm{e}}_{t-1}\right)\right]}{\sum_{t=1}^{t=n} \hat{\mathrm{e}}_{t}^{2}}$

dimana $\mathrm{d}=$ koefisien Durbin-Watson; $\mathrm{t}=$ $\mathrm{t}$ hitung; $\mathrm{n}=$ sampel; $\mathrm{e}=$ residual. Nilai $\mathrm{d}$ yang diperoleh dibandingkan dengan nilai du dan $\mathrm{dL}$, jika $0<\mathrm{d}<\mathrm{dL}$ atau $4-\mathrm{dL}<\mathrm{d}<4$ berarti terdapat autokorelasi, bila nilai $\mathrm{d}$ terletak antara $\mathrm{dL}<\mathrm{d}<\mathrm{du}$ atau $4-\mathrm{du}<\mathrm{d}<\mathrm{d}<\mathrm{dL}$ berarti tidak dapat dipastikan adanya autokorelasi, bilamana $\mathrm{du}<\mathrm{d}<4-$ du berarti tidak ada autokorelasi positif/negatif.
Selajutnya setelah dilakukan pengujian asumsi ekonometrika dilakukan analisis efisiensi produksi. dalam terminologi ilmu ekonomi mengemukakan bahwa efisiensi dapat digolongkan menjadi 3 (tiga) macam, yaitu efisiensi alokatif, efisiensi teknis, dan efisiensi ekonomi. Suatu produksi dikatakan mencapai efisiensi alokatif apabila Nilai Produk Marjinal (NPM) sama dengan harga faktor produksi yang bersangkutan. Nilai Produk Marjinal (NPM) adalah penambahan pendapatan yang diterima akibat pemakaian tambahan unit input. Secara matematis dapat dituliskan sebagai berikut (Soekartawi, 2003) :

$$
N M_{\mathrm{x}}=\mathrm{P}_{\mathrm{x}} \text { atau } \frac{N P M_{x}}{P_{x}}=1
$$

Efisiensi teknis adalah besaran yang menunjukan perbandingan antara produksi sebenarnya dengan produksi maksimum. Perhitungan efisiensi teknis dilakukan dengan menghitung Marginal Physical Product (MPP) dari masing-masing faktor produksi. MPP diperoleh dari turunan pertama fungsi produksi: $\mathrm{Y}=\mathrm{b}_{0} \cdot \mathrm{X}_{1}^{\mathrm{b} 1} \cdot \mathrm{X}_{2}{ }^{\mathrm{b} 2} \cdot \mathrm{X}_{3}{ }^{\mathrm{b} 3} \cdot \mathrm{X}_{4}{ }^{\mathrm{b} 4} \cdot \mathrm{X}_{5}{ }^{\mathrm{b} 5}$ $\mathrm{MPP}=\frac{d Y}{d X}=\mathrm{b}_{0} \cdot \mathrm{b}_{1} \cdot \mathrm{X}_{1}^{\mathrm{b} 1} \cdot \mathrm{X}_{2}{ }^{\mathrm{b} 2} \cdot \mathrm{X}_{3}^{\mathrm{b} 3} \cdot \mathrm{X}_{4}{ }^{\mathrm{b} 4}$. $\mathrm{X}_{5}^{\mathrm{b5}}$

Efisiensi teknis tercapai apabila MPP $=0$. Apabila MPP> 0, berarti penggunaan input produksi belum efisien secara teknis, dan apabila MPP $<0$, berarti penggunaan input tidak efisien secara teknis. Adapun Efisiensi ekonomi adalah besaran yang menunjukakan perbandingan antara keuntungan yang sebenarnya dengan keuntungan maksimum. Secara matematik, hubungan antara efisiensi teknis, efisiensi alokatif dan efisiensi ekonomi adalah sebagai berikut (Soekartawi, 2003):

$\mathrm{EE}=\mathrm{ET} \times \mathrm{EA}$

dimana:

$$
\begin{aligned}
& \mathrm{EE}=\text { Efisiensi Ekonomi } \\
& \mathrm{ET}=\text { Efisiensi Teknis } \\
& \text { EA }=\text { Efisiensi Alokatif }
\end{aligned}
$$

Dengan demikain, bila ET dan EA diketahui, maka EE juga dapat dihitung. Adapun besaran $\mathrm{ET} \leq 1, \mathrm{EA} \leq 1$, dan EE tidak selalu harus kurang atau sama dengan satu 


\section{HASIL PEMBAHASAN}

\section{Keragaan Umum Model}

Hasil pendugaan model faktor produksi karet dalam penelitian ini sangat baik sebagai mana terlihat dari koefisien determinasi (R2) yaitu 0,9470 . Hal ini menunjukkan bahwa 94,70 persen peubah jumlah produksi dapat dijelaskan oleh peubah jumlah tanaman, jumlah tenaga kerja, penggunaan pupuk, umur tanaman, dan modal kerja. Sedangkan 5,30 persen dipengaruhi oleh peubah lain yang tidak termasuk dalam model. Variasi ini signifikan pada taraf nyata 1 persen yang dilihat dari $F$ hitung sebesar 312,69 dan probabilitas <0,0001.

Hasil uji normalitas dengan menggunakan statistik Shapiro-Wilk memperlihatkan bahwa hasil perhitungan statistik Shapiro-Wilk untuk produksi karet sebesar 0,88 . Nilai tersebut signifikan pada taraf nyata 1 persen. Uji multikolinieritas nilai VIF untuk semua peubah independen (jumlah tanaman, umur tanaman, jumlah tenaga kerja, penggunaan pupuk, dan investasi) mempunyai nilai kurang dari 10. Hasil pengujian heteroskedasitas menunjukkan statistik Breusch-pagan sebesar 7,77, nilai tersebut berbedanyata dengan nol pada taraf nyata 5 persen. Nilai Durbin-Watson (DW) pada model yang dibangun yaitu sebesar 2,064, pada $n=60$ dan $\mathrm{k}=6$ dari Tabel distribusi DW dengan taraf nyata 1 persen di peroleh nilai dL sebesar 1,808 dan du sebesar 2,192. Hal ini mengindikasikan bahwa data berditribusi normal, tidak terjadi multikoliniearitar, tidak terjadi heterokedasitas dan tidak terjadi autokorelasi.

Faktor dominan yang mempengaruhi produksi karet dapat dilihat dari hasil pendugaan model penggunaan faktor-faktor produksi usahatani karet pada Tabel 1.

Berdasarkan hasil pendugaan model pada Tabel 1 diketahui bahwa terdapat empat peubah yang berpengaruh nyata terhadap produksi karet rakyat, yaitu jumlah tanaman, umur tanaman, tenaga kerja, dan investasi. Sedangkan jumlah pupuk tidak berpengaruh nyata terhadap produksi karet rakyat di Kabupten kampar.

Koefisien jumlah tanaman memiliki tanda positif yaitu sebesar 0,88329 yang berarti bahwa setiap peningkatan 1 persen jumlah tanaman akan meningkatkan jumlah produksi sebesar 0,88329 persen, demikian pula sebaliknya, setiap terjadi pengurangan 1 persen jumlah tanaman, akan menurunkan jumlah produksi sebesar 0,88329 persen dengan asumsi faktorfaktor produksi lainnya tetap. Hal ini menunjukkan bahwa peubah jumlah tanaman responsif terhadap produksi karet, sehingga dapat memberikan gambaran bahwa faktor jumlah tanaman merupakan faktor produksi yang paling besar pengaruhnya dalam menentukan jumlah produksi karet. Berdasarkan hal tersebut petani masih dapat menambah jumlah tanaman karet yang dibudidayakan karena setiap penambahan input akan meningkatkan output. Hal ini senada dengan kajian Agustina at all (2016)

Hasil estimasi yang di dapat menunjukkan bahwa data umur tanaman berpengaruh negatif terhadap jumlah produksi karet dan berbeda nyata dengan nol pada taraf nyata 10 persen sehingga hipotesis HOditerima dan hopotesis Haditolak. Artinya apabila umur tanaman meningkat maka jumlah produksi akan berkurang. Koefisien umur tanaman memiliki tanda negatif yaitu sebesar $-0,11708$ yang berarti bahwa setiap peningkatan 1 persen umur tanaman akan menurunkan jumlah produksi sebesar 0,11708 persen. Dengan demikian dapat disimpulkan bahwa apabila terjadi penurunan produksi karet karena umur yang sudah tua maka tanaman karet sudah waktunya untuk diremajakan

Tabel 1. Hasil pendugaan model penggunaan faktor-faktor produksi usahatani karet rakyat di Kabupaten Kampar.

\begin{tabular}{|l|r|r|r|r|r|}
\hline \multicolumn{1}{|c|}{ Variabel } & $\begin{array}{c}\text { Parameter } \\
\text { Estimate }\end{array}$ & $\begin{array}{c}\text { Standard } \\
\text { Error }\end{array}$ & t Value & $\operatorname{Pr}>|\mathrm{t}|$ & \multicolumn{1}{c|}{$\begin{array}{c}\text { Variance } \\
\text { Inflation }\end{array}$} \\
\hline Intercept & -0.88355 & 1.13016 & -0.78 & 0.4378 & 0 \\
\hline Jumlah tanaman & 0.88329 & 0.06079 & 14.53 & $<.0001$ & 3.17175 \\
\hline Umur tanaman & -0.11708 & 0.06370 & -1.84 & 0.0716 & 1.39693 \\
\hline Jumlah tenaga kerja & 0.14117 & 0.06030 & 2.34 & 0.0229 & 1.11531 \\
\hline Jumlah pupuk & 0.00221 & 0.00508 & 0.43 & 0.6659 & 1.11590 \\
\hline Investasi & 0.23692 & 0.08901 & 2.66 & 0.0102 & 2.85166 \\
\hline
\end{tabular}


Koefisien tenaga kerja memiliki tanda positif yaitu sebesar 0,14117 yang berarti bahwa setiap peningkatan 1 persen tenaga kerja akan meningkatkan jumlah produksi sebesar 0,14117 persen, demikian pula sebaliknya, setiap terjadi pengurangan 1 persen tenaga kerja, maka akan menurunkan jumlah produksi sebesar 0,14117 persen dengan asumsi faktor produksi lainnya tetap. Pengaruh penggunaan tenaga kerja terhadap produksi bernilai positif sehingga dapat menaikkan produksi karet dengan melakukan peningkatan penggunaan tenaga kerja tanpa mengurangi penggunaan faktor produksi lain. Alokasi waktu kerja petani yang paling besar dalam usahatani adalah tenaga kerja panen. Semakin besar alokasi kerja panen maka produksi (hasil panen) cenderung meningkat. Hal ini senada dengan kajian Rizal (2014), Ronal. S at all (2014), Yarna Hasian (2015), Gede at all (2015), Reni at all (2014), Silvira at all (2013), Felicia at all (2014), Lidya at all (2015), Shelvi at all (2014), Susilawati at all (2015), Stulov (2016), Reny at all (2014) dan Ongki at all (2015).

Koefisien investasi memiliki tanda positif terhadap produksi yaitu sebesar 0,23692 yang berarti bahwa setiap peningkatan 1 persen modal kerja akan meningkatkan jumlah produksi sebesar 0,23692 persen, demikian pula sebaliknya, setiap terjadi pengurangan 1 persen investasi, maka akan menurunkan jumlah produksi sebesar 0,23692 persen dengan asumsi faktor-faktor produksi lainnya tetap. Hal ini menunjukkan bahwa pengaruh investasi terhadap produksi karet responsif hal ini sedana dengan kajian Desi (2015).

\section{Efisiensi Produksi}

Soekartawi (2003) dalam terminologi ilmu ekonomi mengemukakan bahwa efisiensi dapat digolongkan menjadi 3 (tiga) macam, yaitu efisiensi alokatif, efisiensi teknis, dan efisiensi ekonomi. Hasil analisis Efisiensi teknis, efisiensi alokatif atau harga dan efisiensi ekonomi dapat di lihat pada tabel 2.

Hasil perhitungan efisiensi teknis menunjukkan bahwa besaran nilai efisiensi teknis jumlah tanaman, dan tenaga kerja masing-masing sebesar $-21,92$, dan $-8,03$. .
Nilai-nilai tersebut $<0$ (kecil dari nol), artinya penggunaan faktor jumlah tanaman, tenaga kerja dan pupuk tidak efisien secara teknis. Dengan demikian perlu dilakukan penambahan penggunaan faktor jumlah tanaman, tenaga kerja dan pupuk. Sedangkan nilai efisiensi teknis untuk faktor umur tanaman adalah 150,78 , nilai tersubut $>0$ (besar dari nol), artinya faktor umur tanaman belum efisien secara teknis. Dengan demikian perlu dilakukan peremajaan pada tanaman tua/rusak. Sementaraitu, nilai efisiensi teknis penggunaan pupuk dan investasi $=0$ (sama dengan nol), artinya penggunaan penggunaan pupuk dan investasi sudah efisien secara teknis.

Nilai efisiensi alokatif untuk faktor jumlah tanaman, tenaga kerja, dan penggunaan pupuk, masing-masing adalah $-3,06,-3,15$, 0,31 , nilai-nilai tersebut $<1$ (kecil dari satu), artinya bahwa faktor jumlah tanaman, jumlah tenaga kerja dan penggunaan pupuk tidak efisien secara alokatif, dengan demikian perlu dilakukan pengurangan penggunaan faktor produksi.

Hasil pehitungan efisiensi ekonomi memperlihatkan bahwa faktor jumlah tanaman dan tenaga kerja masing-masing sebesar 66,98 dan 25,27, nilai tersebut $>0$ (besar dari nol), artinya penggunaan faktor jumlah tanaman dan jumlah tenaga kerja belum efisien secara ekonomi. Untuk itu perlu dilakukan penambahan penggunaan faktor jumlah tanaman dan jumlah tenaga kerja. Sedangkan hasil nilai efisiensi ekonomi untuk faktor penggunaan pupuk sebesar 0,04 , nilai tersebut $=0$ (sama dengan nol), artinya penggunaan pupuk sudah efisien secara ekonomi.

\section{KESIMPULAN DAN IMPLIKASI KEBIJAKAN}

Faktor-faktor dominan (berbeda nyata secara statistik) yang mempengaruhi produksi karet di Kabupaten kampar adalah jumlah tanaman, umur tanaman, jumlah tenaga kerja dan investasi. Seluruh faktor yang berbeda nyata secara statistik tersebut berpengaruh positif kecuali umur tanaman. Selanjutnya, penggunaan faktor produksi, khususnya jumlah tanaman dan jumlah tenaga kerja, tidak efisien secara teknis, alokatif, dan ekonomis.

Tabel 2. Hasil Analisis Efisiensi Teknis, Efisiensi Alokatif dan Efisiensi Ekonomi

\begin{tabular}{|l|r|r|r|}
\hline Variabel & Efisiensi Teknis & Efisin Alokatif & Efisiensi Ekonomi \\
\hline Jumlah Tanaman & $-21.92^{*}$ & $-3.06^{*}$ & $66.98^{*}$ \\
\hline Tenaga Kerja & $-8.03^{*}$ & $-3.15^{*}$ & $25.27^{*}$ \\
\hline Pupuk & $-0.13^{* * *}$ & $-0.31^{*}$ & $0.04^{* * *}$ \\
\hline
\end{tabular}


Penggunaan pupuk (didominasi oleh pupuk urea) penggunaannya cenderung efisien secara teknis dan ekonomis, namun secara alokatif tidak efisien.

Implikasi kebijakan untuk mengoptimalkan produksi karet di Kabupaten kampar yaitu : Pertama Penggunaan faktor jumlah tanaman pada usahatani karet rakyat di Kabupaten Kampar di ketahui responsif terhadap produksi dan belum mencapai kondisi efisien secara teknis maupun ekonomi, oleh karena itu untuk mengoptimalkan produksi karet petani masih dapat menambah penggunaan faktor jumlah tanaman. Dimana rata-rata penggunaan jumlah tanamn karet rakyat di Kabupaten Kampar adalah 431 batang/hektar, sedangkan untuk memperoleh hasil yang optimal, jarak tanam karet yang direkomendasikan oleh dinas perkebunan Kabupaten Kampar adalah 6 × 3 meter atau jumlah populasi sekitar 550 pohon/hektar. Kedua umur tanaman karet sudah banyak yang tua dan rusak, oleh karenanya perlu dilakukan peremajaan tanaman karet. Peremajaan karet dengan menggunakan bibit unggul dan dipelihara sesuai dengan standar teknik budidaya diyakini akan mampu meningkatkan produktivitas karet yang dihasilkan. Ketiga untuk memperoleh produksi yang lebih optimal dan penggunaan tenaga kerja yang efisien perlu penerapan sistem sadap karet yang tepat disesuaikan dengan kondisi tanaman dan harga karet. Disamping itu penggunaan pupuk berimbang (unsur $\mathrm{N}, \mathrm{P}$, dan $\mathrm{K}$ ) sesuai dengan yang diajurkan perlu diterapkan. Keempat Mencermati kondisi harga karet yang berfluktuasi dan cenderung beragam antara petani maka diperlukan kebijakan pemerintah melalui sistem pemasaran karet yang fair. Disamping itu perlu adanya upaya dari petani untuk mempertahankan kualitas bokar.

\section{DAFTAR PUSTAKA}

Agustina Pasaribu, Djaimi Bakce, Novia Dewi (2016). Analisis Efisiensi Produksi Usahatani Kelapa di Kecamatan Keritang Kabupaten Indragiri Hilir. Jurnal Online Mahasiswa (JOM) Bidang Pertanian Vol 3, No 1:1-11, Februari 2016.

Badan Pusat Statistik. 2014. Statistik Indonesia. Biro Pusat Statistik, Jakarta.
Badan Pusat Statistik. 2014. Riau Dalam Angka 2014. Badan Pusat Statistik Provinsi Riau, Pekanbaru.

Badan Pusat Statistik. 2013. Riau Dalam Angka 2013. Badan Pusat Statistik Provinsi Riau, Pekanbaru.

Badan Pusat Statistik. 2014. Kampar Dalam Angka 2014. Badan Pusat Statistik Kabupaten Kampar, Bangkinang.

Badan Pusat Statistik. 2013. Kampar Dalam Angka 2013. Badan Pusat Statistik Kabupaten Kampar, Bangkinang.

Desi Apriani Damanik (2015). Analisis FaktorFaktor Yang Mempengaruhi Produksi Teh (Studi Kasus: PTPN IV Bahbutong, Kec. Sidamanik, Kab. Simalungun Sumatera Utara). Jurnal Online Mahasiswa (JOM) Bidang Ilmu Ekonomi Vol 2, No 2:1-15, Oktober 2015.

Didit, H dan Adus, A. 2005. Petunjuk Lengkap Budidaya Karet. PTAgroMedia Pustaka, Jakarta.

Direktorat Jendral Perkebunan Kementrian Pertanian. 2013. Pedoman Teknis Pengembangan Tanaman Karet tahun 2014, Jakarta.

Felicia Marisa Sinabariba, Fembriarti Erry Prasmatiwi dan Suriaty Situmorang (2014). Analisis Efisiensi Produksi Dan Pendapatan Usahatani Kacang Tanah di Kecamatan Terbanggi Besar Kabupaten Lampung Tengah. Jurnal Ilmu-Ilmu Agribisnis Universitas Lampung Vol 2, No 4 :316-322, Oktober 2014.

Gede Wegananda ajar Sangurjana, IWayan Widyantara dan Ida Ayu Listia Dewi (2016). Efektivitas dan Efisiensi Penggunaan Faktor Produksi Usahatani Cabai Besar di Desa Baturiti Kecamatan Baturiti Tabanan. E-journal Agribisnis dan Agrowisata Universitas Udayana Vol.5 No.1:1-11, Januari 2016.

Gujarati, D, 2003. Basic Econometrics. Fourth Edition. International. Edition Mc GrawHill, Singapore:

Hanke, J. E., A. G. Reitsch, and D. W. Wichern. 2001. Business Forecasting. Seventh Edition. Prentice-Hall, Inc. Upper Saddle River, New Jersey.

Hair, J.F. JR, R. E. Rolph, R. L. Tatham, and W. C. Black. Multivariate Data Analysis. Prentice-Hall Internationa, Inc., New Jersey. 
Koutsoyiannis, A. 1977. Theory of Econometrics. Harper and Row Publisher Inc, New York.

Ongki Fermadi, Fembriarti Erry Prasmatiwi, Eka Kasymir (2015). Analisis Efisiensi Produksi Dan Keuntungan Usahatani Jagung di Kabupaten Ogan Komering Ulu Timur Sumatera Selatan. Jurnal Ilmu-Ilmu Agribisnis Universitas Lampung Vol 3, No $1: 107-113$, Januari 2015.

Reni Ismawati, Cepriadi, Roza Yulida (2014). Analisis Faktor Produksi Terhadap Produksi Semangka (Citrullus Vulgaris, Scard) di Kecamatan Tampan Kota Pekanbaru. Jurnal Online Mahasiswa (JOM) Bidang Pertanian Vol 1, No 1:1-14, Februari 2014.

Reny Novianty Sinaga, Dian Wijayanto dan Dardiyatno (2014). Analisis Pengaruh Faktor Produksi Terhadap Pendapatan dan Volume Nelayan Cantrang di Pelabuhan Perikanan Nusantara. Journal of Fisheries Resources Utilization Management and Technology Vol 3, No.2:85-93.

Rizal R (2014). Analisis Efisiensi Penggunaan Input Produksi Usahatani Padi sawah di Desa Toribulu Kecamatan Toribulu Kabpaten Parigi Moutong. Journal Agroland Universitas Tadulako Vol.1 No.1 :29-36, April 2014.

Ronal Simorangkir, max Nur Alam dan Abdul Muis (2014). Analisis Efisiensi Penggunaan Input Produksi Usahatani Jagung Manis di Desa Maku Kecamatan Dolo Kabupaten Sigi. Journal Agroland Universitas Tadulako Vol.21 No.1:37-44, April 2014.

Salvatore, D. 2011. Managerial Ekonomics dalam Pekonomian Global. Erlangga, Jakarta.

Shelvi Sriyanti, Suardi Tarumun dan Yusmini (2014). Analitytic of Production Factors Towards Updown Farming Enterprise Productivity Sungai Beringin Village Tembilahan Sub District Indragiri Hilir Regency. Jurnal Online Mahasiswa (JOM) Bidang Pertanian Vol 1, No 1:1-12, Februari 2014.
Silvira, Hasman Hasyim dan Lily Fauzia (2013). Analisis Faktor-faktor yang mempengaruhi Produksi Padi Sawah (Studi Kasus: Desa Medang, Kecamatan Medang Deras Kabupaten Batu Bara). Journal On Social Economic of Agriculture And Agribusiness Vol 2, No 4:1-12, 4 April 2013.

Soekartawi. 1990.Teori Ekonomi Produksi dengan Pokok Bahasan Analisis Fungsi Cobb-Douglas. PT. Raja Grafindo Persada, Malang.

Soekartawi. 2003. Teori Ekonomi Produksi; Pokok Bahasan Analisis Fungsi CobbDouglass, Cetakan Ketiga, PT. Raja Grafindo Persada, Jakarta.

Susilawati, Sugeng Yudiono dana di Suyatno (2015). Analisis efisiensi alokatif FaktorFaktor Produksi Usahatani Jagung Hibrida Di Kawasan Usaha Agribisnis Terpadu (Kuat) Rasau Jaya Komplek Kabupaten Kubu Raya. Jurnal Social Economic of Agriculture Vol 4, No 2:88-102, Desember 2015.

Stulov. V.V (2016). Increase in Production Efficiency Due to the Use of Modernized Rubber_Processing Rollers. Journal of Machinery Manufacture and Reliability, 2016, Vol. 45, No. 1: 78-82, Maret 2016.

Pindyck, R. S. and D. L. Rubinfeld. 1991. Econometric Models and Economic Forcasts. Third Edition. McGraw-Hill Inc, New York.

Thomas, R.L. 1997. Modern Economometrics an Introduction. Addison Wesley Longman, Harlow.

Verbeek, M., KU Leuven, and Tilburg University. 2000. A Guide to Modrn Econometrics. Jonh Wiley and Sons Ltd., Chichester.

Widarjono, A. 2009. Ekonometrika Pengantar dan Aplikasi untuk Ekonomi dan Bisnis. Ekonisia, Jakarta.

Yarna Hasiani (2015). Efisiensi Faktor-faktor Produksi Usaha Pembesaran Ikan NIla Dalam Karamba Jaring aapung di Kabupaten Banjar. Journal EnviroScienteae Vo.11 No.3:187-192, November 2015. 
